\title{
Structural analysis of Leucocine - an essential bacteriocin
}

\author{
Hirak Jyoti Chakraborty, Sayak Ganguli*, Protip Basu, Paushali Roy and Abhijit Datta \\ *DBT-Centre for Bioinformatics, Presidency College, Kolkata, sayakbif@yahoo.com
}

\begin{abstract}
Bacterial peptides of low molecular weight displaying antagonism towards other bacterial members are referred to as bacteriocins. Bacteriocins are an essential member of the broadly classified group of lantibiotics which finds several commercial uses. This work comprises of the determination of structure of the most important class of bacteriocins - the leucocin group. Structure elucidation was performed using homology modelling approach and the modeled structure was validated using their Ramachandran calculations. Ligand interaction pockets were identified by calculating the Delaunay triangulation number and structural properties of amino acids were documented. Structure elucidations of such lantibiotics are important for future endeavours towards analyses of protein - protein interactions.
\end{abstract}

Key Words- Lantibiotics, bacteriocin, homology modelling, Pocket Identification

\section{Introduction}

Molecules isolated from bacteria that have demonstrated bactericidal activity are called bacteriocins. Ribosomally synthesized peptide bacteriocins from Gram-positive bacteria can be subdivided into two major classes. Bacteriocins of class I are characterized by having modified amino acid residues (e.g., lantibiotics) and bacteriocins of class II are characterized by not possessing modified amino acid residues (e.g., small heat stable non-lantibiotics). These two classes are the most studied due to their abundance and their potential use for industrial applications. They are similar in size (approx 2060 amino acids), mostly cationic, and possess a hydrophobic domain and/or amphiphilic region, which may relate to their activity on membranes. The defining characteristic of lantibiotics is that they contain the unusual amino acids lanthionine or $\beta$-methyllanthionine. Generally, type A lantibiotics are characterized by being strongly cationic (with 2 to 7 net positive charge), having molecular masses more than $2100 \mathrm{Da}$, and having rigid ring conformations separated by areas of flexibility [1]. It is currently believed that their primary bactericidal activity is mediated through the formation of voltage-dependent membrane channels. By contrast, type B lantibiotics are characterized by being neutral or slightly anionic with a 0 to -1 net charge, having molecular masses of less than $2100 \mathrm{Da}$, and having a more compact globular structure. The main function lies in the inhibition of the essential enzymes. Two peptide bacteriocins are unique as, two genes encoding each of the peptides are located next to each other and both of the peptides are required for bactericidal activity. As their bactericidal activity resembles type I lantibiotics they are often classified as the type I class [2]. Lantibiotics are produced by a large number of Gram positive bacteria such as Streptococcus and Streptomyces to attack other gram positive bacteria and as such they are considered a member of the bacteriocins [3]. Lantibiotics are well studied because of the commercial use of these bacteria in the food industry for making dairy products such as cheese. Posttranslational modification events and their extents are the basis for the classification of the bacteriocins. The lantibiotics are a class of more extensively modified bacteriocins, also called Class I. Bacteriocins for which disulfide bonds are the only modification to the peptide are Class II bacteriocins [2]. Nisin and epidermin are members of a family of lantibiotics that bind to a cell wall precursor lipid component of target bacteria and disrupt cell wall production. The duramycin families of lantibiotics bind phosphoethanolamine in the membranes of its target cells and seem to disrupt several physiological functions. The name Lantibiotics was introduced in 1988 as an abbreviation for "Lanthionine-containing peptide antibiotics". In spite of this naming, Lantibiotics are not classed as antibiotics. One reason for this is that they are constructed ribosomally while antibiotics are constructed by enzyme action. The first structures of these antimicrobial agents were produced by pioneering work by Gross and Morell in the late sixties and early seventies, thus marking the formal introduction of Lantibiotics. Since then Lantibiotics such as Nisin have been used auspiciously for food preservation and have yet to encounter significant bacterial resistance. These attributes of lantibiotics have led to more detailed research into their structures and biosynthetic pathways. Type A Lantibiotics are long flexible molecules - e.g., Nisin, subtilin, epidermin. Subgroup Al includes Mutacin II, subgroup All includes Mutacin I \& III. Type B Lantibiotics are globular - eg mersacidin, actagardine, cinnamycin. The biosynthesis is interesting. They are synthesized with a leader polypeptide sequence which is only removed during the transport of the molecule out of the synthesizing cell. They are synthesized by ribosome's, which distinguishes them from antibiotics which are synthesized by enzymes. Lantibiotics show substantial specificity for some components (eg lipid II) of bacterial cell membranes especially of Gram positive bacteria. Type A kill rapidly by pore formation, type B inhibit peptidoglycan biosynthesis. They are 
active in very low concentrations. Lantibiotics are produced by Gram-positive bacteria and show strong antimicrobial action towards a wide range of other Gram-positive bacteria. As such they have become attractive candidates for use in food preservation (by inhibiting pathogens that cause food spoilage) and the pharmaceutical industry (to prevent or fight infections in humans or animals).

Bacteriocins are antibacterial compounds that are produced from lactic acid bacteria and their lethality lies in the fact that they are able to create pores in the bacterial membrane thus causing lysis of the target cell. Examples of bacteriocins are nisin and leucocin. Nisin inhibits the growth of most gram-positive bacteria, particularly sporeformers (e.g., Clostridium botulinum. This bacteriocin has been approved for use as a food preservative in the United States since 1989. Leucocin is inhibitory to the growth of Listeria monocytogenes. Lactic acid bacteria are also of economic importance in the preservation of agricultural crops. A popular method of crop preservation utilizes what is termed silage. In this method crop plants are exposed to lactic acid bacteria which results in the lowering of the surface $\mathrm{pH}$ and prevents the growth of other microorganisms [4].

\section{Materials and Method}

The sequences of the lantibiotics were obtained from the Genbank nucleotide collection at the NCBI [5] home page. All the available sequences were primarily downloaded as a batch file and then were subjected to the analyses. Primarily the sequences were subjected to homology analysis through BLASTp to retrieve the nearest homologues. All the sequences were then collected to generate a pool of 300 sequences. From this pool each sequence was selected and was subjected to BLAST search against the Protein Databank (PDB) [6]. This resulted in the derivation of several suitable templates on which the structure could be modeled on. The best template was found to be that of Bacteriocin Carnobacteriocin B2 (1RY3). Using this template the structures were then modeled using Modeller 9.2. Once the modeled structure was obtained then the rotamer and Ramachandran angles were tested at the Mol probity server and were substantiated using the VADAR program. The Delaunay triangulation score of each of the residues were then estimated and then best six binding pockets were identified using the CASTp server.

\section{Results and Discussion}

The modeled structure (Fig 1) did not show any outliers in the Ramachandran angles and rotamer evaluations (Fig 3 ) indicating that all the residues were in the allowed regions.[7] The data obtained from the VADAR server[8] (Fig 2) were correlated with the pocket identification [9] results (Fig 4) and it was found that all the residues that were found to be the part of any of the identified pockets had a very high accessible surface area (> 85) indicating that the residue exposure was suitable for them to interact with possible ligands or other interacting proteins. Modeling of Leucocine is an important step in understanding the actual mode of action of this class of bacteriocin as it has several beneficial roles in the agricultural arena.

\section{References}

[1] James Leif Smith PHD thesis University Of Florida 2002.

[2] Paul D. Cotter, Colin Hill, and R. Paul Ross. (2005) Current Protein and Peptide Science, 6, 61-75.

[3] Cindy van Kraaij, Willem M. de Vos, Roland J. Siezen and Oscar P. Kuipers. (1999) Nat. Prod. Rep., 16, 575-587

[4] http://www.enotes.com/microbiologyencyclopedia/lactic-acid-bacteria

[5] www.ncbi.nlm.nih.gov

[6] www.pdb.org

[7] Ian W. Davis, Andrew Leaver-Fay, Vincent B. Chen, Jeremy N. Block, Gary J. Kapral, Xueyi Wang, Laura W. Murray, W. Bryan Arendall III, Jack Snoeyink, Jane S. Richardson and David C. Richardson (2007) Nucleic Acids Research 35 Web Server issue, W375W383.

[8] Leigh Willard, Anuj Ranjan,Haiyan Zhang,Hassan Monzavi, Robert F. Boyko, Brian D. Sykes, and David S. Wishart Nucleic Acids Res. 2003; 31 (13): 3316.3319

[9] Joe Dundas, Zheng Ouyang, Jeffery Tseng, Andrew Binkowski, Yaron Turpaz, and Jie Liang (2006) Nucleic Acid Research, 34:W116-W118. 


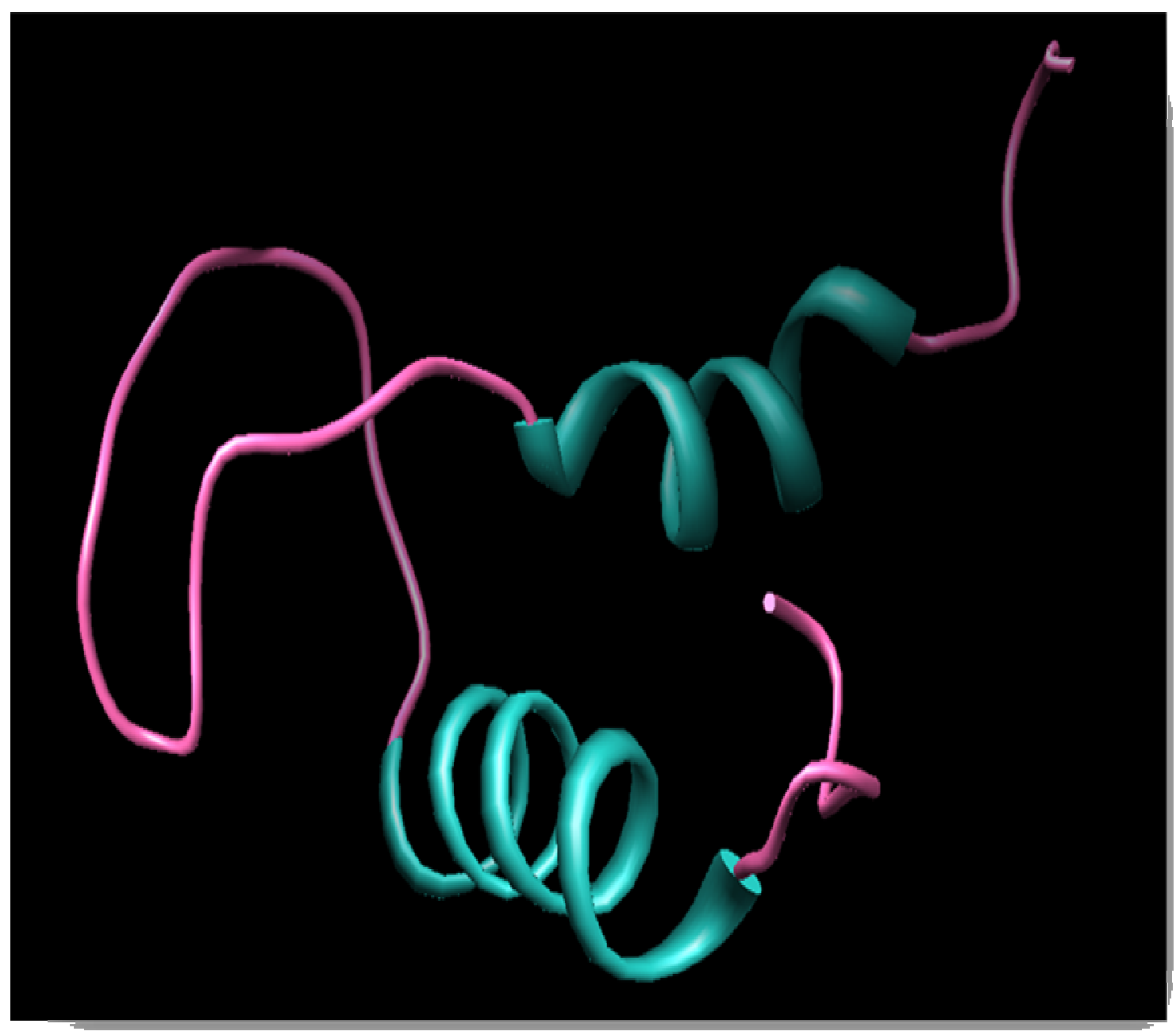

Fig. 1-Modeled structure of Leucocine. (Green - Helices, Pink - Coils) [obtained using Chimera] 


\begin{tabular}{|c|c|c|c|c|c|c|c|c|c|c|c|c|}
\hline $\begin{array}{l}\text { RES. } \\
\text { NUM. }\end{array}$ & $\begin{array}{l}\text { RES. } \\
\text { NAME }\end{array}$ & $\begin{array}{l}\text { SCND } \\
\text { STRU }\end{array}$ & & $\begin{array}{l}\text { HBOND } \\
\text { HBOND }\end{array}$ & $\begin{array}{l}\text { BIURN } \\
\text { BIURN }\end{array}$ & $\begin{array}{l}\text { RES. } \\
\text { ASA. }\end{array}$ & $\begin{array}{l}\text { FRAC. } \\
\text { ASA }\end{array}$ & $\begin{array}{l}\text { RES. } \\
\text { VOI. }\end{array}$ & $\begin{array}{l}\text { FRAC. } \\
\text { VOI. }\end{array}$ & $\begin{array}{l}\text { PHI } \\
\text { PHI }\end{array}$ & $\begin{array}{l}\text { PSI } \\
\text { PSI }\end{array}$ & $\begin{array}{l}\text { OMEGA } \\
\text { OMEGA }\end{array}$ \\
\hline 1 & MET & $\operatorname{ccc}$ & $c$ & & & 141.3 & 0.65 & 167.1 & 1.02 & 360.0 & -108.2 & -178.4 \\
\hline 1 & MEI & $\operatorname{ccc}$ & c & & & 190.2 & 0.87 & 144.3 & 0.88 & -63.4 & -35.2 & -179.1 \\
\hline 3 & ASN & $\mathrm{CBC}$ & c & & & 103.1 & 0.62 & 115.1 & 0.98 & -123.9 & -170.3 & 178.8 \\
\hline 4 & MET & CBC & c & & & 152.4 & 0.70 & 147.2 & 0.90 & -71.5 & 145.9 & -176.7 \\
\hline 5 & LYS & CBC & c & 7 & & 91.8 & 0.43 & 143.4 & 0.93 & -149.6 & -171.8 & 174.2 \\
\hline 6 & PRO & $\operatorname{ccc}$ & c & & & 143.4 & 0.93 & 107.9 & 0.94 & -64.9 & -30.8 & 172.3 \\
\hline 7 & THR & $\operatorname{ccc}$ & C & 5 & & 63.2 & 0.42 & 106.0 & 0.91 & -79.0 & 133.8 & -174.1 \\
\hline 8 & GLU & $\mathrm{CHC}$ & c & & & 90.8 & 0.48 & 136.3 & 1.02 & -73.1 & 140.9 & -179.8 \\
\hline 9 & SER & НHн & $\mathrm{H}$ & 12,13 & & 27.9 & 0.21 & 94.8 & 1.05 & -79.7 & -8.6 & -174.3 \\
\hline 10 & TYR & ннН & $\mathrm{H}$ & 13,14 & & 159.5 & 0.66 & 169.7 & 0.89 & -62.4 & -50.8 & -175.7 \\
\hline 11 & GLU & ннн & $\mathrm{H}$ & 14,15 & & 101.0 & 0.53 & 125.9 & 0.94 & -69.0 & -43.8 & -173.8 \\
\hline 12 & GLN & ннН & $\mathrm{H}$ & 16,15 & & 63.0 & 0.33 & 140.0 & 1.01 & -64.0 & -45.0 & -177.6 \\
\hline 13 & LEU & ннн & $\mathrm{H}$ & 9,17 & & 120.8 & 0.58 & 159.6 & 0.98 & -66.7 & -39.9 & -172.6 \\
\hline 14 & Asp & HнH & $\mathrm{H}$ & 10,18 & & 68.2 & 0.43 & 97.0 & 0.85 & -59.7 & -37.7 & -179.4 \\
\hline 15 & ASN & ннн & H & 11,19 & & 106.6 & 0.64 & 121.2 & 1.03 & -63.8 & -50.3 & -176.4 \\
\hline 16 & SER & ннн & $\mathrm{H}$ & 20,19 & & 47.4 & 0.36 & 85.7 & 0.95 & -63.7 & -34.2 & -177.1 \\
\hline 17 & ALA & НнН & $\mathrm{H}$ & 13,21 & & 33.3 & 0.27 & 71.7 & 0.82 & -62.4 & -46.8 & -176.8 \\
\hline 18 & LEU & $\mathrm{HHH}$ & $\mathrm{H}$ & 14,21 & & 92.3 & 0.44 & 144.7 & 0.89 & -65.1 & -32.9 & -177.2 \\
\hline 19 & GLU & ннн & $\mathrm{H}$ & 15,16 & & 37.9 & 0.20 & 157.6 & 1.18 & -61.8 & -42.6 & -177.6 \\
\hline 20 & GLN & ннН & $\mathrm{H}$ & 16,17 & & 90.7 & 0.48 & 125.7 & 0.90 & -68.3 & -34.8 & -175.6 \\
\hline 21 & VAI & ннН & $\mathrm{H}$ & 17,18 & & 106.7 & 0.62 & 109.7 & 0.81 & -62.8 & -46.3 & -173.0 \\
\hline 21 & VAI & ннН & $\mathrm{H}$ & 18,19 & & 128.6 & 0.75 & 120.2 & 0.88 & -56.8 & -47.5 & -179.3 \\
\hline 23 & GLY & $\mathrm{CCH}$ & c & 19,20 & & 42.1 & 0.46 & 67.6 & 1.07 & 142.2 & -154.9 & -178.3 \\
\hline 23 & GLY & $\operatorname{ccc}$ & c & & & 66.0 & 0.73 & 53.0 & 0.84 & -119.0 & -175.9 & -179.2 \\
\hline 25 & LYS & $\operatorname{ccc}$ & c & & & 95.6 & 0.45 & 171.5 & 1.11 & -159.2 & -173.8 & -177.2 \\
\hline 26 & TYR & $\operatorname{ccc}$ & c & & & 198.1 & 0.82 & 163.7 & 0.86 & -114.5 & -158.6 & -176.0 \\
\hline 26 & TYR & $\operatorname{ccc}$ & c & & & 183.0 & 0.76 & 168.8 & 0.88 & -61.2 & -50.2 & 170.5 \\
\hline 28 & GLY & $\operatorname{ccc}$ & C & & & 37.7 & 0.41 & 50.4 & 0.80 & 46.0 & 54.1 & 179.6 \\
\hline 29 & ASN & $\operatorname{ccc}$ & c & & & 106.4 & 0.64 & 93.7 & 0.80 & -73.5 & -177.8 & 173.5 \\
\hline 30 & GLY & $\mathrm{ccc}$ & C & & & 82.0 & 0.90 & 48.0 & 0.76 & 59.2 & 50.8 & 177.4 \\
\hline 31 & VAI & $\mathrm{CBC}$ & c & & & 95.3 & 0.55 & 116.3 & 0.86 & -86.7 & 160.6 & 178.4 \\
\hline 32 & HIS & $\mathrm{CBC}$ & C & & & 131.9 & 0.65 & 137.0 & 0.88 & -120.6 & 163.4 & -176.3 \\
\hline 33 & CYS & CBC & c & & & 68.9 & 0.48 & 85.3 & 0.82 & -87.7 & 87.1 & 177.9 \\
\hline 34 & THR & $\mathrm{CBC}$ & C & 36 & & 89.8 & 0.59 & 103.0 & 0.88 & -139.3 & 127.6 & 177.6 \\
\hline 35 & LYS & $\mathrm{ccc}$ & c & & & 196.1 & 0.91 & 136.7 & 0.89 & 59.4 & 13.5 & -178.5 \\
\hline 36 & SER & $\mathrm{CCC}$ & c & 34 & & 79.0 & 0.60 & 81.5 & 0.90 & -166.9 & 177.2 & 177.9 \\
\hline 37 & GLY & $\operatorname{ccc}$ & $c$ & & & 57.1 & 0.63 & 65.0 & 1.03 & -69.0 & 141.0 & -174.4 \\
\hline 38 & CYS & $\mathrm{ccc}$ & $c$ & & & 51.9 & 0.36 & 101.8 & 0.97 & -70.9 & -42.5 & -176.2 \\
\hline 39 & SER & CBC & c & & & 105.9 & 0.80 & 78.3 & 0.86 & $-112 \cdot 6$ & 142.2 & 175.3 \\
\hline 40 & VAI & $\mathrm{CBC}$ & c & & & 97.0 & 0.56 & 109.0 & 0.80 & -128.0 & 146.2 & 177.1 \\
\hline 41 & ASN & $\mathrm{CBC}$ & C & & & 125.1 & 0.76 & 91.2 & 0.78 & -76.5 & 137.6 & -179.7 \\
\hline 42 & TRP & $\mathrm{CBC}$ & C & & & 177.4 & 0.67 & 166.8 & 0.72 & -97.9 & 165.9 & -179.3 \\
\hline 43 & GLY & $\operatorname{ccc}$ & $c$ & 46 & III & 21.5 & 0.24 & 47.9 & 0.76 & 95.7 & 19.6 & 176.4 \\
\hline 44 & GLU & $\mathrm{CHC}$ & c & 47 & III & 27.5 & 0.14 & 101.3 & 0.76 & -66.2 & -35.6 & -178.7 \\
\hline 45 & ALA & ннн & $\mathrm{H}$ & 48,49 & III & 52.0 & 0.42 & 68.8 & 0.79 & -64.3 & -33.3 & -171.5 \\
\hline 46 & PHE & ннН & $\mathrm{H}$ & 43,50 & III & 137.2 & 0.60 & 151.9 & 0.78 & -52.4 & -46.6 & -178.5 \\
\hline 47 & SER & НHн & $\mathrm{H}$ & 51,50 & & 75.9 & 0.58 & 75.7 & 0.84 & -59.4 & -42.8 & -176.2 \\
\hline 48 & ALA & ннн & $\mathrm{H}$ & 45,51 & & 69.0 & 0.56 & 70.4 & 0.81 & -63.1 & -43.1 & -176.0 \\
\hline 49 & GLY & ннн & $\mathrm{H}$ & 45,53 & & 28.0 & 0.31 & 52.1 & 0.83 & -64.4 & -40.5 & -175.9 \\
\hline 50 & VAL & HHH & $\mathrm{H}$ & 46,54 & & 51.4 & 0.30 & 109.1 & 0.80 & -63.9 & -22.1 & 176.1 \\
\hline 51 & HIS & ннн & $\mathrm{H}$ & 47,48 & & 140.9 & 0.69 & 126.6 & 0.81 & -54.3 & -54.7 & 178.1 \\
\hline 52 & ARG & HHH & $\mathrm{H}$ & 49,55 & & 183.7 & 0.75 & 144.9 & 0.83 & -69.8 & -39.8 & -173.4 \\
\hline 53 & LEU & нн & $\mathrm{H}$ & 49,50 & & 134.4 & 0.65 & 126.5 & 0.77 & -62.0 & -37.7 & -176.0 \\
\hline 54 & ALA & $\mathrm{CHH}$ & $\mathrm{H}$ & 50,51 & & 60.2 & 0.49 & 67.3 & 0.77 & -61.1 & -47.0 & 179.7 \\
\hline 55 & ASN & $\mathrm{CCH}$ & $c$ & 51,52 & & 105.8 & 0.64 & 88.5 & 0.75 & 54.0 & 36.6 & -174.8 \\
\hline 56 & GLY & $\mathrm{CcC}$ & c & & & 67.8 & 0.75 & 51.0 & 0.81 & 69.2 & -126.0 & 179.2 \\
\hline 56 & GLY & $\operatorname{ccc}$ & c & & & 52.2 & 0.58 & 48.3 & 0.77 & -133.5 & 94.6 & 176.2 \\
\hline 58 & ASN & $\mathrm{ccc}$ & c & & & 126.4 & 0.76 & 91.3 & 0.78 & -92.3 & 93.5 & 178.0 \\
\hline 59 & GLY & $\operatorname{ccc}$ & c & & & 50.4 & 0.55 & 49.6 & 0.79 & 76.7 & 178.7 & 179.4 \\
\hline 60 & PHE & $\operatorname{ccc}$ & c & & & 221.8 & 0.98 & 150.4 & 0.77 & 54.3 & 36.3 & -179.9 \\
\hline 61 & TRP & $\operatorname{ccc}$ & c & & & 278.9 & 1.05 & 185.2 & 0.80 & -124.4 & 360.0 & 360.0 \\
\hline
\end{tabular}

Fig. 2- Surface area calculations along with the propensity of hydrogen bond formation of the individual residues. (obtained from VADAR) 


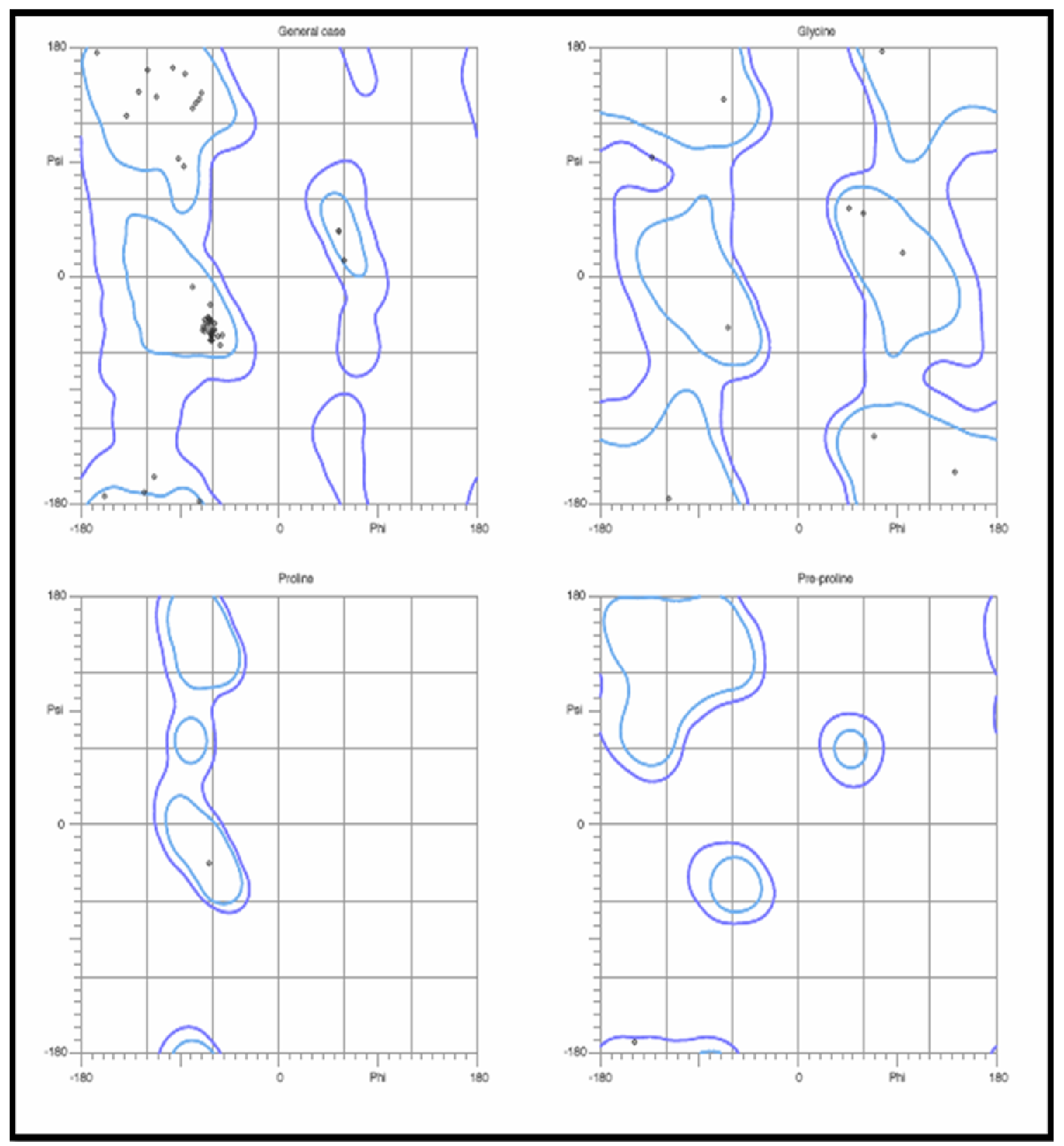

Fig. 3- Ramachandran plot of the modeled structure. (obtained from Molprobity server) 


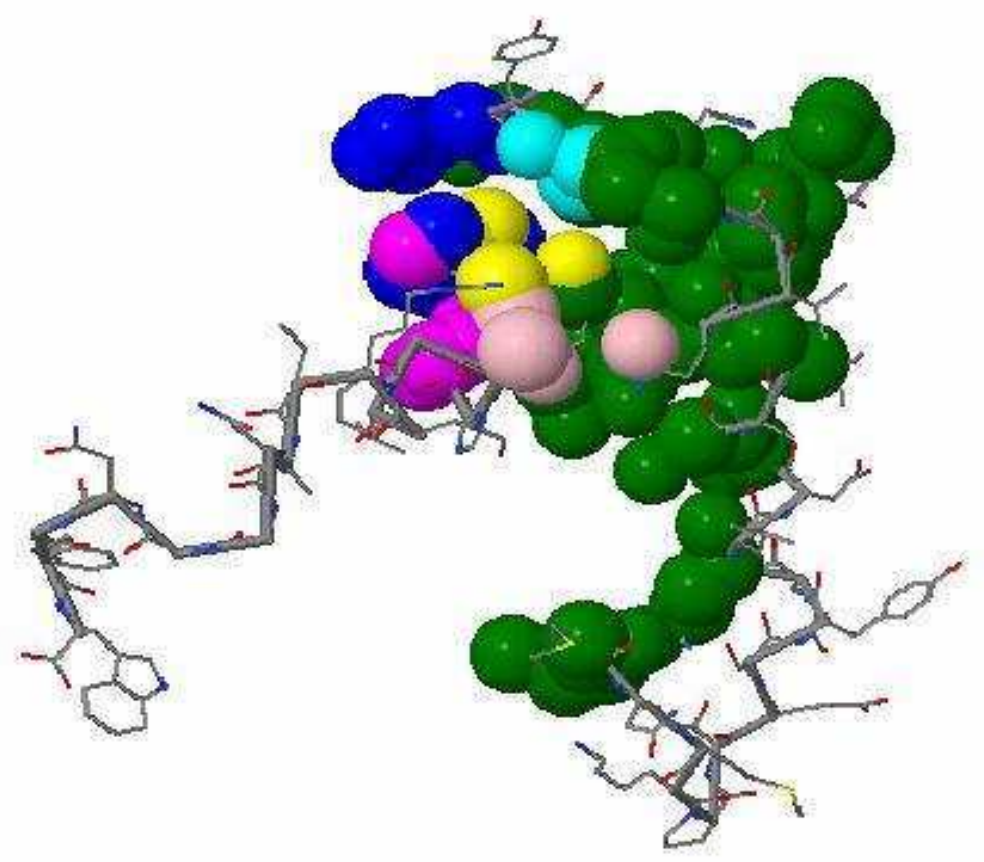

1. MMNMKPTESY EOLDNSALEQ VVGGKYYGNG VHCTKSGCSV NWGE FSAGV 51. HRLANGGNGF W

Fig. 4- Possible interacting pockets as calculated using the Delaunay triangulation number. [Screenshot of CASTp] 